\title{
Correction to: Why public health matters today and tomorrow: the role of applied public health research
}

\author{
Lindsay McLaren ${ }^{1} \cdot$ Paula Braitstein ${ }^{2} \cdot$ David Buckeridge $^{3} \cdot$ Damien Contandriopoulos $^{4} \cdot$ Maria I. Creatore $^{5}$. \\ Guy Faulkner $^{6}$. David Hammond ${ }^{7}$. Steven J. Hoffman ${ }^{8} \cdot$ Yan Kestens $^{9} \cdot$ Scott Leatherdale ${ }^{7}$. Jonathan McGavock ${ }^{10}$. \\ Wendy V. Norman ${ }^{11}$. Candace Nykiforuk ${ }^{12}$. Valéry Ridde ${ }^{13,14} \cdot$ Janet Smylie $^{2}$
}

Published online: 2 September 2020

(C) The Author(s) 2020

\section{Correction to: Can J Public Health https://doi.org/10.17269/s41997-019-00196-2}

The article "Why public health matters today and tomorrow: the role of applied public health research," written by Lindsay McLaren et al., was originally published Online First without Open Access. After publication in volume 110 , issue 3 , pages $317-322$ the author decided to opt for Open Choice and to make the article an Open Access publication. Therefore, the copyright of the article has been changed to (C) The Author(s) 2019 and the article is forthwith distributed under the terms of the Creative Commons Attribution 4.0 International License, which permits use, sharing, adaptation, distribution and reproduction in any medium or format, as long as you give appropriate credit to the original author(s) and the source, provide a link to the Creative Commons licence, and indicate if changes were made. The images or other third party material in this article are included in the article's Creative Commons licence, unless indicated otherwise in a credit line to the material. If material is not included in the article's Creative Commons licence and your intended use is not permitted by statutory regulation or exceeds the permitted use, you will need to obtain permission directly from the copyright holder. To view a copy of this licence, visit http://creativecommons.org/licenses/by/4.0.

Open Access This article is licensed under a Creative Commons Attribution 4.0 International License, which permits use, sharing, adaptation, distribution and reproduction in any medium or format, as long as

The online version of the original article can be found at https://oi.org/ 10.17269/s41997-019-00196-2

Lindsay McLaren

lmclaren@ucalgary.ca

University of Calgary, Calgary, Canada

2 University of Toronto, Toronto, Canada

3 McGill University, Montreal, Canada

4 University of Victoria, Victoria, Canada

5 CIHR Institute of Population \& Public Health, University of Toronto, Toronto, Canada

6 University of British Columbia, Vancouver, Canada

7 University of Waterloo, Waterloo, Canada
CIHR Institute of Population \& Public Health, York University, Toronto, Canada

9 Université de Montréal, Montreal, Canada

10 Children's Hospital Research Institute of Manitoba, University of Manitoba, Winnipeg, Canada

11 University of British Columbia, Vancouver, Canada

12 University of Alberta, Edmonton, Canada

13 IRD (French Institute For Research on Sustainable Development), CEPED (IRD-Université Paris Descartes), ERL INSERM SAGESUD, Université Paris Sorbonne Cités, Paris, France

14 University of Montreal Public Health Research Institute (IRSPUM), Montreal, Canada 
you give appropriate credit to the original author(s) and the source, provide a link to the Creative Commons licence, and indicate if changes were made. The images or other third party material in this article are included in the article's Creative Commons licence, unless indicated otherwise in a credit line to the material. If material is not included in the article's Creative Commons licence and your intended use is not permitted by statutory regulation or exceeds the permitted use, you will need to obtain permission directly from the copyright holder. To view a copy of this licence, visit http://creativecommons.org/licenses/by/4.0/.

Publisher's note Springer Nature remains neutral with regard to jurisdictional claims in published maps and institutional affiliations. 